\title{
PENGARUH SEMANGAT KERJA TERHADAP KINERJA PERANGKAT NAGARI DALAM PENGELOLAAN KEUANGAN NAGARI DI KABUPATEN PESISIR SELATAN
}

\author{
Seprima Yenti \\ Jurusan Ilmu Administrasi Negara, Fakultas Ilmu Sosial, Universitas Negeri Padang \\ seprimayenti25@gmail.com
}

\begin{abstract}
The purpose of this study is to analyze the effect of work spirit on the performance of nagari apparatus in Nagari financial management in Pesisir Selatan Regency. The background of this study is due to the low work spirit of Nagari apparatus in Koto XI Tarusan and Bayang subdistrict which is still so that it has an impact on Nagari financial management that is not optimal. The method used in this study is a quantitative method with the form of associative research. The population in this study was of Nagari apparatus in Koto XI Tarusan and Bayang Subdistrict, totaling 140 respondents. The sample in this study consisted of 126 Nagari apparatus which were determined using the Slovin formula with an error rate of 5\% and the sampling technique using the Proportionate Stratifed Random Sampling technique. Data collection technique in this study are using questionnaires distributed to respondents with measurement using a Likert scale. The data obtained are then analyzed using multiple linear regression. The results of this study indicate that the work spirit variable (simultaneously) has a significant effect on the performance of nagari apparatus in nagari financial management with a significance value of 0,000 and the value of Adjust $R$ Square 0.295. Thus, the influence of work spirit on the performance of nagari apparatus in managing nagari finances is $29.5 \%$. While the remaining $70.5 \%$ is influenced by other variables not examined in this study.
\end{abstract}

Keywords: Work Spirit, Performance, Nagari Financial Management

\begin{abstract}
ABSTRAK
Tujuan dari penelitian ini adalah untuk menganalisis pengaruh semangat kerja terhadap kinerja perangkat nagari dalam pengelolaan keuangan nagari di Kabupaten Pesisir Selatan. Penelitian ini dilatarbelakangi oleh rendahnya semangat kerja perangkat Nagari di Kecamatan Koto XI Tarusan dan Bayang sehingga berdampak pada pengelolaan keuangan Nagari yang tidak optimal. Metode yang digunakan dalam penelitian ini adalah metode kuantitatif dengan bentuk penelitian asosiatif. Populasi dalam penelitian ini adalah perangkat Nagari di Kecamatan Koto XI Tarusan dan Bayang, yang berjumlah 140 responden. Sampel dalam penelitian ini terdiri dari 126 perangkat Nagari yang ditentukan menggunakan rumus Slovin dengan tingkat kesalahan 5\% dan teknik pengambilan sampel menggunakan teknik Proportionate Stratifed Random Sampling. Teknik pengumpulan data dalam penelitian ini menggunakan kuesioner yang dibagikan kepada responden dengan menggunakan skala likert. Data yang diperoleh kemudian dianalisis menggunakan regresi linier berganda. Hasil penelitian ini menunjukkan bahwa variabel semangat kerja (secara simultan) berpengaruh signifikan terhadap kinerja perangkat nagari dalam pengelolaan keuangan nagari dengan nilai signifikansi 0,000 dan nilai Adjust R Square 0,295. Dengan demikian, pengaruh semangat kerja terhadap kinerja perangkat nagari dalam pengelolaan keuangan nagari di Kabupaten Pesisir Selatan adalah sebesar 29,5\%. Sedangkan sisanya 70,5\% dipengaruhi oleh variabel lain yang tidak diteliti dalam penelitian ini.
\end{abstract}

Kata Kunci: Semangat Kerja, Kinerja, Pengelolaan Keuangan Nagari 


\section{Pendahuluan}

Dalam rangka menciptakan tata kelola pemerintahan yang baik (good governance), maka pemerintah Indonesia terus melakukan berbagai usaha untuk meningkatkan transparansi dan akuntabilitas pengelolaan keuangan negara (Romdhoni, 2017). Adanya otonomi daerah merupakan suatu peluang yang besar bagi pemerintah daerah untuk melaksanakan keuangan daerahnya dengan lebih baik, yaitu lebih nyata dan bertanggungjawab. Pemberian kewenangan dan kemampuan menggali sumber keuangan sendiri yang didukung oleh perimbangan keuangan antara pemerintah pusat dan daerah, dan antara provinsi dan kabupaten/kota merupakan suatu bentuk penyelenggaran dari otonomi daerah yang nyata. Hal ini bertujuan untuk mempercepat tercapainya masyarakat yang sejahtera melalui peningkatan kualitas pelayanan, pemberdayaan masyarakat dan keikutsertaan masyarakat.

Berkaitan dengan hal tersebut dalam meningkatkan kesejahteraan masyarakat, maka dilaksanakan program dana desa. Kebijakan tentang pengelolaan dana desa diatur dalam Permendagri Nomor 113 Tahun 2014 Tentang pengelolalan Keuangan Desa, yang menyatakan bahwa keuangan desa adalah segala kegiatan yang mencakup perencanaan, pelaksanaan, penatausahaan, pelaporan dan pertanggungjawaban keuangan desa, yang telah menjadi hak dan kewajiban desa yang dapat menjadi milik desa sesuai dengan pelaksanaan hak dan kewajiban tersebut. Dimana tujuan dana desa berdasarkan UU Nomor 6 Tahun 2014 Tentang Desa, adalah meningkatkan pelayanan publik di desa, mengentaskan kemiskinan, memajukan perekonomian desa, mengatasi kesenjangan pembangunan antar desa, serta memperkuat masyarakat desa sebagai subjek dari pembangunan, namun lebih di prioritaskan kepada pelayanan dan pembangunan.

Kemudian berdasarkan Peraturan Bupati Pesisir Selatan No. 69 Tahun 2016 tentang Pedoman Pengelolaan Keuangan Nagari, bahwasanya pemegang kekuasan pengelolaan keuangan nagari adalah Walinagari yang karena jabatannya mempunyai kewenangan menyelenggarakan keselurahan pengelolaan keuangan nagari. Pengelolaan keuangan nagari harus dikelola secara tertib, taat pada peraturan perundang-undangan, efektif, efisien, ekonomis, transparan, dan bertanggung jawab dengan memperhatiakn asas keadilan, kepatuhan, dan manfaat untuk masyarakat. Walaupun sudah dijelaskan dan diatur dalam Peraturan Bupati bagaimana seharusnya pengelolaan keuangan nagari tersebut,di lapangan masih banyak ditemukan pelanggaran atau penyimpangan mengenai penggunaan dana nagari. ICW merangkum adanya peningkatan kasus korupsi dalam pengelolaan anggaran desa, yaitu ada sekitar 106 kasus korupsi yang terjadi sepanjang Tahun 2015 sampai September 2017, dimana menetapkan sebanyak 101 Kepala Desa dan 6 Perangkat Desa yang terlibat (Detik news:2017).

Salah satu contoh permasalahan pengelolaan keuangan nagari di Kabupaten Pesisir Selatan adalah, tiga Walinagari di Kabupaten Pesisir Selatan yang diduga pungli dan selewengkan dana desa. Tiga wali nagari tersebut adalah Walinagari Air Haji Tenggara, Walinagari Air Haji Barat dan Walinagari Koto Berapak. Selain itu juga terdapat masalah keterlambatan dalam pencairan Dana Desa, dimana hingga pada Bulan Mei 2018 lalu, baru 20\% Dana Desa (DD) yang telah dicairkan pada nagari. Keterlambatan tersebut menurut Kepala Bidang Pemerintahan Nagari terkait dengan belum keluarnya Peraturan Bupati Pesisir Selatan tentang Petunjuk Teknis dan Petunjuk Pelaksanaan Dana Desa. Dan juga masalah masih kurangnya sarana dan prasana dalam pengelolaan keuangan nagari yaitu masih belum adanya Wifi kantor serta jaringan internet yang masih belum lancar sehingga menghambat dalam pelaksanaan pengelolaan keuangan nagari dan penyelesaian pekerjaan. Selain itu Rahmadi (2017) yang menyatakan permasalahan dalam pengelolaan keuangan nagari di Kabupaten Pesisir Selatan antara lain, keterlambatan pencairan anggaran dan pelaksanaan 
program/kegiatan, kesalahan dalam penatausahaan keuangan dan pembuatan surat pertanggungjawaban, serta keterlambatan penyusunan dan penyampaian laporan keuangan.

Kemudian di lapangan juga ditemukan permasalahan dalam pengelolaan keuangan nagari diantaranya adalah faktor manajemen sumber daya manusia atau perangkat nagari itu sendiri. Salah satunya adalah permasalahan yang berhubungan dengan semangat kerja. Hal ini terlihat dari masih terdapat aparatur nagari yang mempunyai semangat kerja yang rendah, terlihat dari masih seringnya perangkat nagari yang absen masuk kantor, masih rendahnya tingkat kedisiplinan perangkat nagari dengan masih banyaknya terdapat perangkat nagari yang sering terlambat datang masuk kantor dan balik di jam yang lebih cepat. Hal ini tentunya akan berpengaruh terhadap pengelolaan keuangan nagari.

Senada dengan hal tersebut, kepala urusan keuangan Nagari Kapuh Utara Kecamatan Koto X1 Tarusan pada tanggal 1 April 2019, mengatakan bahwa masih ditemukannya permasalahan dalam melakukan pengelolaan keuangan nagari karena semangat kerja dari perangkat nagari itu sendiri. Kemudian permasalahan lainnya berkaitan dengan masih lemahnya semangat kerja perangkat nagari disebabkan karena kerja sama yang masih kurang baik antara perangkat nagari dalam pengelolaan keuangan. Seperti diungkapkan oleh Sekretaris Nagari Pasar Baru Kecamatan Bayang pada tanggal 11 Maret 2019 yang mengatakan masih kurangnya kerjasama antara rekan kerja, sehngga dalam pembuatan laporan pertanggung jawaban sering terlambat karena sering tidak tepat waktunya penyelesaian laporan pertanggungjawaban dari setiap kegitan yang dilakukan.

Selanjutnya berdasarkan hasil penelitian terdahulu yang penulis temukan bahwa terdapat hasil penelitian yang menyatakan bahwa semangat kerja berpengaruh secara signifikan/positif terhadap kinerja seperti hasil penelitian yang dilakukan oleh (Syahropi, 2016) dan (Handayani, 2016) dan (Pratama dan Wardani, 2017). Dan selanjutnya ada juga hasil penelitian yang menyatakan bahwa semangat kerja tidak berpengaruh signifikan terhadap kinerja, seperti penelitian yang dilakukan oleh (Haryadi, 2016) tentang pengaruh Semangat Kerja Dan Disiplin kerja Terhadap Kinerja Pegawai Puskesmas dengan hasil penelitian diperoleh bahwa semangat kerja memiliki hubungan yang negatif terhadap kinerja pegawai.

Berlandaskan dari berbagai permasalahan serta penelitian terdahulu di atas, maka penulis telah melakukan penelitian tentang pengaruh semangat kerja terhadap kinerja perangkat nagari dalam pengelolaan keuangan nagari di Kabupaten Pesisir Selatan. Penelitian ini merupakan intisari dari hasil penelitian skripsi dan penelitian payung yang dilakukan oleh (Syamsir, 2017) dengan judul Model Pembinaan Aparatur Pemerintahan Nagari dalam Pengelolaan Keuangan Nagari di Kabupaten Tanah Datar. Adapun rumusan masalah yang penulis kemukakan dalam penelitian ini adalah: Apakah terdapat pengaruh semangat kerja terhadap kinerja perangkat nagari dalam pengelolaan keuangan nagari di Kabupaten Pesisir Selatan?

\section{Tinjuan Kepustakaan}

\section{Kinerja}

Kinerja merupakan hasil-hasil fungsi pekerjaan/kegiatan seseorang atau kelompok dalam suatu organisasi yang dipengaruhi oleh berbagai faktor untuk mencapai tujuan organisasi dalam periode waktu tertentu. Menurut Suntoro (dalam Nawawi, 2013) kinerja (performance) merupakan pencapaian hasil kerja seseorang atau kelompok orang dalam suatu organisasi sesuai dengan wewenang dan tanggung jawabnya dalam rangka mencapai tujuan organisasi secara legal, tidak melanggar hukum dan sesuai dengan moral dan etika. Sedangkan menurut Colquitt, Lepine dan Wesson (dalam Wibowo, 2016) mengemukan 
bahwa kinerja merupakan nilai serangkaian tingkah laku pekerja yang memberikan sumbangan, baik secara positif maupun negatif, terhadap pencapaian tujuan organisasi.

Menurut (Syamsir dan Baiyulis, 2018) gambaran dari kinerja menyangkut tiga komponen utama yaitu terdiri dari tujuan, ukuran, dan penilian. Dimana penentuan tujuan dari setiap unit organisasi merupakan suatu strategi untuk meningkatkan kinerja, dan tujuan akan memberikan arah dan mempengaruhi perilaku kerja dari setiap personel terhadap apa yang diharapkan organisasi. Maka dapat ditarik kesimpulan bahwa kinerja merupakan suatu hasil yang diperoleh/ dicapai oleh seorang pegawai dalam menjalankan tugasnya sesuai dengan amanah yang diberikan padanya.

(Murty dan Hudiwinarsih, 2012) menyatakan bahwa kinerja dipengaruhi oleh beberapa faktor-faktor yaitu faktor personal yang terdiri dari pengetahuan, keterampilan, kemampuan, kepercayaan diri, dan dukungan kerja, faktor kepemimpinan yang terdiri dari kualitas manajer, semangat, arahan, dan dukungan kerja, dan faktor tim yang terdiri dari kualitas dukungan dan semangat yang diberikan oleh rekan satu tim, kepercayaan sesama anggota tim, kekompakan dan keeretan tim, serta faktor sistem yang terdiri dari sistem kerja, fasilitas kerja, infrastruktur, proses organisasi, dan budaya kerja dalam organisasi. Kemudian (Syamsudin, 2005) mengatakan bahwa kinerja dipengaruhi oleh pengalaman pegawai, semangat kerja pegawai, dan pengawasan dari pemimpin.

\section{Semangat Kerja dan Kinerja}

Semangat kerja merupakan suatu keadaan psikologis yang menimbulkan kesenangan dan mendorong seseorang untuk bekerja dengan giat dan konsekuen dalam mencapai tujuan yang ditetapkan oleh organisasi. (Hasibuan, 2005) mengatakan bahwa semangat kerja adalah kemauan dan keyakinan seseorang melaksanakan pekerjaannya dengan baik serta berdisiplin agar mencapai produktifitas yang maksimal. Selanjutnya Nitisemo (dalam Siagian, 2010) mengatakan bahwa semangat kerja adalah melaksanakan pekerjaan dengan lebih giat, agar pekerjaan terselesaikan dengan lebih baik dan efisien. Sedangkan (Griffin dan Elbert, 2007) mengatakan semangat kerja adalah keseluruhan perilaku karyawan terhadap lingkungan kerja mereka yang tinggi, dimana semangat kerja mencerminkan sejauh mana mereka merasa bahwa kebutuhan mereka terpenuhi oleh pekerjaaaan mereka.

Di samping itu, (Flippo, 2005) menjelaskan bahwa terdapat empat (4) faktor yang mempengaruhi semangat kerja yang dapat dijadikan indikator untuk mengukur semangat kerja, yaitu:

1. Tingkat absensi, yaitu sesuatu yang membuktikan ketidakhadiran pekerja dalam tugasnya, termasuk waktu yang hilang sebab sakit, kecelakaan dan pergi meninggalkan pekerjaan karena alasan-alasan pribadi, baik diberi wewenang atau tidak.

2. Kerja sama, yaitu suatu bentuk perbuatan bersama-sama seseorang dengan orang lain, yang terlihat dari kesiapan para karyawan untuk bekerjasama dengan orang-orang disekitar mereka dengan dilandaskan untuk mencapai tujuan bersama; kesedian untuk saling membantu; serta adanya keaktifan di dalam kegiatan-kegiatan organisasi.

3. Kepuasan kerja, adalah suatu keadaan emosional pegawai terhadap nilai balas jasa kerja pegawai dengan tingkat nilai balas jasa yang memang diinginkan oleh pegawai yang bersangkutan.

4. Kedisiplinan, yaitu dapat diukur dari tingkat kepatuhan seseorang pada aturan dan tata tertib yang ditetapkan.

Banyak penelitian yang dilakukan oleh para peneliti tentang pengaruh semangat kerja terhadap kinerja seseorang atau kinerja organisasi. Temuan tersebut membuktikan hasil yang tidak sama. Ada hasil temuan yang mendukung terhadap teori yang ada, dan ada pula yang 
menentang terhadap teori yang ada. Temuan penelitian yang mendukung teori tersebut yaitu dibuktikan oleh hasil penelitian yang ditemukan oleh (Syahropi, 2016) yang berjudul Pengaruh Semangat Kerja Terhadap Kinerja Karyawan PT. Bangkinang Di Pekanbaru (Studi Kasus Pada karyawan Tetap PT. Bangkinang), dengan hasil penelitian menyatakan bahwa semangat kerja berpengaruh positif dan signifikan terhadap kinerja karyawan. Hal ini dapat dilihat dari hasil olahan angket dengan menggunakan uji regresi dengan hasil perhitungan regresi memperlihatkan bahwa thitung yang lebih besar dari t tabel yaitu 11,205> 1,998 dan hasil Sig 0,000<0,05 yang mempunyai makna bahwa semangat kerja mempunyai pengaruh yang positif dan signifikan terhadap kinerja karyawan. Selanjutnya hasil penelitian (Handayani, 2016) yang berjudul Pengaruh Lingkungan Kerja dan Semangat Kerja terhadap Kinerja PNS Balitsa Lembang, menyatakan bahwa secara parsial semangat kerja memiliki pengaruh yang signifikan terhadap kinerja pegawai. Kemudian (Pratama dan Wardani, 2017) meneliti tentang Pengaruh Kemampuan Kerja dan Semangat Kerja Terhadap Kinerja Karyawan Melalui Kepuasan Kerja, dengan hasil penelitian yaitu bahwa kemampuan kerja, semangat kerja, dan kepuasan kerja secara simultan berpengaruh signifikan terhadap kinerja karyawan dengan pengaruh sebesar 50,9\%; sisanya 49,1\% dipengaruhi oleh variabel lain di luar model tersebut. Kemudian hasil penelitian yang menyatakan semangat kerja tidak berpengaruh terhadap kinerja diantaranya adalah temuan yang diperoleh dari penelitian (Haryadi, 2016) yang berjudul Pengaruh Semangat Kerja Dan Disiplin Kerja Terhadap Kinerja Pegawai Puskesmas Kecamatan Maronge Kabupaten Sumbawa Tahun 2015 dengan hasil penelitian diperoleh bahwa semangat kerja mempunyai pengaruh yang negatif terhadap kinerja pegawai, dengan koefisien regresi sebesar -0,227 yang artinya apabila semangat kerja meningkat sebesar 1 satuan, maka kinerja akan menurun sebesar -0,227 satuan.

\section{Pengelolaan Keuangan Desa/Nagari dan Indikator Pengukur Kinerja dalam Pengelolaan Keuangan Nagari}

Pengelolaan keuangan desa/nagari tidak hanya tentang perlunya aturan pendukung dan sarana-prasarana, tetapi yang paling perlu adalah adanya SDM yang mempunyai kompetensi, semangat kerja yang tinggi, dan komitmen yang dapat diandalkan sehingga pengalokasian keuangan nagari tersebut menjadi tepat guna dan tepat sasaran. Diberlakukannya UU No. 6 Tahun 2014 tentang Desa, maka pemerintahan desa harus ikut mengelola keuangan desa dan dapat mempertanggungjawabkannya. Dalam pasal 1 UU No. 6 Tahun 2014 tentang desa dijelaskan bahwa keuangan desa/nagari adalah segala hak dan kewajiban desa/nagari yang dapat dinilai dengan uang, serta segala sesuatu berupa uang dan barang yang berhubungan dengan pelaksanaan hak dan kewajiban desa.

Di Indonesia peraturan yang mengurus tentang Panduan Pengelolaan Keuangan Desa secara umum adalah Permendagri Nomor 113 Tahun 2014 Tentang Pengelolaan Keuangan Desa. Dimana Pengelolaan Keuangan Desa adalah semua kegiatan yang dilaksanakan oleh kepala desa/nagari dan perangkatnya mulai dari perencanaan, penatausahaan, pelaksanaan, pelaporan, dan pertanggungjawaban keuangan desa/nagari.

Selain itu pengelolaan keuangan nagari juga di atur dalam Peraturan Pemerintah Nomor 47 Tahun 2015 tentang Peraturan Pelaksanaan Undang-Undang Nomor 6 Tahun 2014 tentang Desa pasal 1 ayat 8 , yaitu yang dimaksud dengan dana desa adalah dana yang bersumber dari anggaran pendapatan dan belanja negara yang diperuntukkan bagi desa yang ditransfer melalui anggaran pendapatan dan belanja daerah kabupaten/kota dan digunakan untuk membiayai penyelanggaraan pemerintahan, pelaksanaan, pembangunan, pembinaan kemasyarakatan, dan pemberdayaan masyarakat.

Menurut (Murtiono, 2016) pengelolaan keuangan desa/nagari adalah keseluruhan kegiatan yang meliputi perencanaan, pelaksanaan, penatausahaan, pelaporan, dan 
pertanggungjawaban keuangan desa. Pengelolaan keuangan dikelola dalam masa 1 (satu) tahun anggaran yakni mulai tanggal 1 Januari sampai dengan tanggal 31 Desember. Keuangan desa pada dasarnya merupakan subsistem dari keuangan negara sebagaimana diatur dalam Undang-Undang Nomor 17 Tahun 2003 tentang Keuangan Negara. Dalam Permendagri No. 113 Tahun 2014 tentang Pedoman Pngelolaan Keuangan Desa di dalamnya disebutkan bahwa pengelolaan desa dilakukan secara transparan, akuntabel, partisipatif serta tertib dan disiplin anggaran.

Sesuai dengan itu, (Murtiono, 2016) menyatakan indikator untuk mengukur kinerja pemerintah nagari dalam pengelolaan keuangan nagari dapat dilihat dari:

1. Transparan, yaitu suatu prinsip keterbukaan yang memungkinkan masyarakat untuk mengatahui dan mendapatkan akses informasi seluas-luasnya tentang APBDesa.

2. Akuntabel, yaitu prinsip perwujudan kewajiban seseorang untuk dapat mempertanggungjawabkan pengelolaan dan pengendalian sumber daya dan pelaksanaan kebijakan yang dipercayakan kepadanya dalam rangka pencapaian tujuan yang telah ditetapkan.

3. Partisipatif, yaitu bahwa pengelolaan keuangan desa harus memberikan ruang seluasluasnya kepada masyarakat untuk dapat terlibat secara aktif dalam setiap tahapan proses pengelolaan keuangan desa.

4. Tertib dan displin anggaran, yaitu bahwasanya APB Desa harus dikelola secara tepat waktu dan tepat guna serta didukung dengan bukti-bukti administrasi yang dapat dipertanggungjawabkan dan berpedoman pada peraturan yang berlaku.

Selanjutnya dalam pasal 2 Peraturan Bupati Pesisir Nomor 64 Tahun 2016 tentang Susunan Organisasi dan Tata Kerja Pemerintahan Nagari dijelaskan bahwa Perangkat Nagari terdiri Sekretariat Nagari, Pelaksana Kewilayahan dan Pelaksana Teknis. Sekretariat Nagari dipimpin oleh Sekretaris Nagari dan dibantu oleh unsur staf sekretariat yaitu urusan tata usaha dan umum, urusan perencanaan, dan urusan keuangan. Selanjutnya Pelaksana Kewilayahan adalah Kepala Kampung. Sedangkan Pelaksana Teknis terdiri dari beberapa seksi, yaitu kepala seksi pemerintahan dan kepala seksi kesejahteraan dan pelayanan.

\section{Metode Penelitian}

Metode penelitian yang digunakan dalam penelitian ini adalah metode penelitian kuantitatif. Dimana penelitian kuantitatif merupakan penelitian yang menggunakan aspek pengukuran, perhitungan, rumus, dan kepastian data numerik baik didalam penelitian, proses, hipotesis, turun kelapangan, analisa data dan kesimpulan data sampai dengan penulisannya. Populasi dalam penelitian ini terdiri dari perangkat nagari di Kecamatan Koto XI Tarusan dan Kecamatan Bayang Kabupaten Pesisir Selatan.Sampel dalam penelitian ini berjumlah 126 responsden diperoleh dengan menggunakan rumus Slovin. Adapun teknik pengambilan sampel yaitu menggunakan teknik Proportionate Stratifed Random Sampling.

Teknik pengumpulan data penelitian ini yaitu dikumpulkan melalui penyebaran angket kepada responden dengan 4 opsi jawaban berdasarkan pengukuran menggunakan skala Likert yang terdiri dari (sangat setuju, setuju, kurang setuju, dan tidak setuju). Kemudian data di analisis dengan teknik analisis regresi linear berganda. Sebelum uji regresi perlu dilakukannya uji asumsi klasik sebagai persyaratan dalam uji regresi. Serta untuk mendapatkan gambaran umum tentang kedua variable juga digunakan frekuensi, mean, dan TCR. 


\section{Hasil Penelitian dan Pembahasan}

\section{Hasil Penelitian}

Dalam penelitian ini akan menjawab rumusan masalahnya yaitu: apakah terdapat pengaruh semangat kerja (yang mencakup keempat sub variabel yaitu tingkat absensi, kerja sama, kepuasan kerja, dan kedisiplinan) terhadap kinerja perangkat nagari dalam pengelolan keuangan nagari di Kabupaten Pesisir Selatan? Untuk menjawab pertanyaan penelitian tersebut dapat dilihat hasil analisis data temuan penelitian pada tabel berikut:

Tabel 1. Hasil Uji Autokorelasi Pengaruh Semangat Kerja Terhadap Kinerja Perangkat Nagari dalam Pengelolaan Keuangan Nagari

\begin{tabular}{|c|c|c|c|c|c|}
\hline & Model Summary & \\
Model & R & R Square & $\begin{array}{c}\text { Adjusted R } \\
\text { Square }\end{array}$ & $\begin{array}{l}\text { Std. Error of } \\
\text { the Estimate }\end{array}$ & Durbin-Watson \\
\hline 1 & $.563^{\mathrm{a}}$ & .318 & .295 & .22378 & 1.718 \\
\hline
\end{tabular}

a. Predictors: (Constant), Kedisiplinan, Kerja Sama, Kepuasan Kerja, Tingkat Absensi

b. Dependent Variable: Rata-Rata Pengelolaan Keuangan Nagari

Tabel 2. Hasil Uji Anova (F) Pengaruh Semangat Kerja terhadap Kinerja Perangkat Nagari dalam Pengelolaan Keuangan Nagari

Anova $^{b}$

\begin{tabular}{|cc|c|c|c|c|c|}
\hline \multicolumn{2}{|c|}{ Model } & $\begin{array}{c}\text { Sum of } \\
\text { Squares }\end{array}$ & Df & $\begin{array}{c}\text { Mean } \\
\text { Square }\end{array}$ & F & Sig. \\
\hline \multirow{2}{*}{1} & Regression & 2.819 & 4 & .705 & 14.074 & $.000^{\text {a }}$ \\
& Residual & 6.059 & 121 & .050 & & \\
& Total & 8.878 & 125 & & & \\
\hline
\end{tabular}

a. Predictors: (Constant), Kedisiplinan, Kerja Sama, Kepuasan Kerja, Tingkat Absensi

b. Dependent Variable: Rata-Rata Pengelolaan Keuangan Nagari

Berdasarkan Tabel 1 di atas dapat diterangkan bahwa nilai Adjusted $R$ Square yang diperoleh dari analisis regresi sebesar 0,295. Yaitu bahwa, besarnya pengaruh variabel semangat kerja terhadap kinerja perangkat nagari dalam pengelolan keuangan nagari secara simultan adalah sebesar $29,5 \%$. Sementara sisanya sebesar $70,5 \%$ dipengaruhi oleh faktor lain yang tidak ditelusuri dalam penelitian ini. Disini semangat kerja memiliki pengaruh signifikan terhadap kinerja perangkat nagari dalam pengelolaan keuangan nagari. Secara simultan nilai signifikansi variabel lebih kecil dari 0,05, maka Ho di tolak dan Ha diterima. Selain itu, jika diperhatikan hasil uji Anova pada Tabel 2 di atas dapat pula di lihat bahwa hasil atau angka signifikansi pengaruh menunjukkan angka $0.000^{\mathrm{a}}$. Artinya, kebenaran kesimpulan hasil uji regresi ini bisa diyakini hingga $100 \%$.

Selanjutnya, jawaban dari rumusan masalah dalam penelitian ini adalah: Apakah terdapat pengaruh secara sendiri-sendiri dari aspek tingkat absensi, kerja sama, kepuasan kerja dan kedisiplinan (sebagai sub variabel semangat kerja) terhadap kinerja perangkat nagari dalam pengelolaan keuangan nagari di Kabupaten Pesisir Selatan? Secara singkat, hasil uji regresi untuk menjawab rumusan masalah dijelaskan berdasarkan Tabel 3 berikut in: 
Tabel 3. Pengaruh Sub Variabel Semangat Kerja Secara Parsial terhadap Kinerja Perangkat Nagari dalam Pengelolaan Keuangan Nagari

\begin{tabular}{lcccc}
\hline \multicolumn{1}{c}{ Sub Variabel } & R & R Square & Adjusted R Square & Sig. \\
\hline Tingkat Absensi & $.220^{\mathrm{a}}$ & .048 & .041 & $.013^{\mathrm{b}}$ \\
\hline Kerja Sama & $.524^{\mathrm{a}}$ & .274 & .269 & $.000^{\mathrm{b}}$ \\
\hline Kepuasan Kerja & $.190^{\mathrm{a}}$ & .036 & .028 & $.033^{\mathrm{b}}$ \\
\hline Kedisiplinan & $.108^{\mathrm{a}}$ & .012 & .000 & $.228^{\mathrm{b}}$ \\
\hline
\end{tabular}

Berdasarkan tabel 3 di atas dapat dipahami bahwa nilai Adjusted $R$ Square untuk subvariabel tingkat absensi adalah 0,041, yang dapat diartikan pengaruh variabel tingkat absensi terhadap kinerja perangkat nagari dalam pengelolaan keuangan nagari sebesar $4,1 \%$ dan sisanya sebesar 95,9\% dipengaruhi oleh variabel lain. Selanjutnya nilai Adjusted $R$ Square subvariabel kerja sama adalah sebesar 0,269, yang artinya pengaruh variabel kerjasama terhadap kinerja perangkat nagari dalam pengelolaan keuangan nagari adalah $26,9 \%$ dan sisanya sebesar $72,1 \%$ dipengaruhi oleh variabel lain. Sementara nilai Adjusted $R$ Square untuk sub variabel kepuasan kerja adalah 0,028, yang artinya pengaruh variabel kepuasan kerja terhadap kinerja perangkat nagari dalam pengelolaan keuangan nagari sebesar 2,8\% dan sisanya sebesar 97,2\% dipengaruhi oleh variabel lain. Kemudian nilai Adjusted $R$ Square untuk sub variabel kedisiplinan adalah sebesar 0,004, yang artinya pengaruh variabel kedisiplinan terhadap kinerja perangkat nagari dalam pengelolaan keuangan nagari sebesar $0,4 \%$ dan sisanya sebesar 99,6\% dipengaruhi oleh variabel lain.

Kemudian jika dilihat dari hasil uji Anova pada kolom tabel signifikansi menunjukkan secara berurut dari sub variabel tingkat absensi, kerja sama, kepuasan kerja, dan kedisiplinan yaitu 0,013,0,000,0,033, dan 0,228. Yang mana angka tersebut menunjujkkan bahwa angka 0,013,0,000, dan 0,033 lebih kecil dari 0,05 yang berarti bahwa sub variabel tingkat absensi, kerja sama, dan kepuasan kerja berpengaruh secara signifikan terhadap kinerja perangkat nagari dalam pengelolaan keuangan nagari di Kabupaten Pesisir Selatan dan dapat dipercaya. Sedangkan untuk angka 0.228 lebih besar dari 0,05 maka sub variabel kedisiplinan tidak berpengaruh secara signifikan terhadap kinerja perangkat nagari dalam pengelolaan keuangan nagari di Kabupaten Pesisir Selatan. Kemudian hasil rumusan hipotesis penelitian menghasilkan bahwa secara simultan terdapat pengaruh semangat kerja terhadap kinerja perangkat Nagari dalam pengelolaan keuangan Nagari di Kabupaten Pesisir Selatan. Sedangkan secara parcial terdapat pengaruh tingkat absensi, kerja sama, dan kepuasan kerja terhadap kinerja perangkat nagari dalam pengelolaan keuangan nagari di Kabupaten Pesisir Selatan, dan tidak terdapat pengaruh kedisiplinan terhadap kinerja perangkat nagari dalam pengelolaan keuangan nagari di Kabupaten Pesisir Selatan.

\section{Pembahasan}

Hasil penelitian tentang pengaruh semangat kerja terhadap kinerja perangkat nagari dalam pengelolaan keuangan nagari di Kabupaten Pesisir Selatan membuktikan bahwa secara parsial (sendiri-sendiri), variabel tingkat absensi (X1), kerja sama(X2) dan kepuasan kerja(X3) berpengaruh terhadap kinerja perangkat nagari dengan nilai signifikan secara berurutan yaitu, $0.013,0.000$ dan 0,033 . Hal ini mendukung teori atau hasil temuan yang dilakukan oleh Bayulis dan Syamsir (2018) yang menyatakan bahwa kepuasan kerja memiliki pengaruh secara signifikan terhadap kinerja perangkat nagari dalam Pengelolaan keuangan nagari. Namun kedisiplinan (X4) tidak memiliki pengaruh yang besar terhadap kinerja perangkat nagari di Kabupaten Pesisir Selatan dengan nilai signifikan yaitu 0,228. Sedangkan secara simultan semangat kerja memiliki pengaruh secara signifikan terhadap kinerja perangkat nagari dalam pengelolaan keuangan nagari di Kabupaten Pesisir Selatan dengan nilai signifikansi 0.000, yaitu berarti Ho ditolak dan Ha diterima. 
Dari hasil penelitian di atas dapat dikatakan bahwa hasil penelitian ini dapat memperjelas dan memperkuat teori-teori yang telah dijelaskan pada bagian kajian teori bahwa semangat kerja berpengaruh terhadap kinerja. Begitu juga dari teori yang dikemukan oleh (Hasibuan, 2005) yang mengatakan bahwa semangat kerja adalah keinginan dan kesungguhan seseorang mengerjakan pekerjaannya dengan baik serta disiplin untuk mencapai produktifitas yang maksimal. Selain itu, juga dapat membuktikan teori yang dikemukan oleh (Syamsudin, 2005) yang mengatakan bahwa kinerja dipengaruhi oleh 3(tiga) faktor, yaitu semangat kerja pegawai, pengalaman pegawai, dan pengawasan dari pemimpin. Kemudian juga (Syahropi, 2016), yang menyatakan bahwa semangat kerja berpengaruh positif dan signifikan terhadap kinerja karyawan, dengan semangat kerja yang tinggi maka dapat meningkatkan kinerja, maka diperlukan adanya peningkatan kualitas kinerja yang selalu memberikan masukan dari perusahaan terutama pimpinan perusahaan agar semangat kerja karyawan terus dipertahankan dan perlu ditingkatkan agar semangat kerja karyawan itu bisa mencapai tujuan dari perusahaan. Lain halnya dengan yang dipaparkan oleh (Handayani, 2016) yang menyatakan bahwa secara parsial semangat kerja memiliki pengaruh yang signifikan terhadap kinerja pegawai, upaya meningkatkan semangat kerja sangat perlu dilakukan seperti dengan peningkatan kesejahteraan pegawai sehingga kinerja pegawai juga dapat meningkat. Hal ini menunjukkan bahwa semangat kerja yang baik tentu akan dapat mempengaruhi kinerja seseorang menjadi lebih baik karena semangat kerja itu merupakan suatu dorongan yang datang dari dalam diri pegawai tersebut yang membuatnya bergairah untuk meyelesaikan tugas yang diberikan kepadanya dan berkeinginan untuk menghasilkan hasil yang memuaskan untuk organisasi dan untuk dirinya.

\section{Penutup}

Berdasarkan uraian hasil temuan dan pembahasan yang telah dijelaskan sebelumnya, maka dapat penulis simpulkan bahwa:

1. Variabel Semangat kerja (X) terhadap Variabel Pengelolaan Keuangan Nagari (Y) secara simultan memiliki pengaruh terhadap pengelolaan keuangan nagari di Kabupaten Pesisir Selatan. Maka Ho ditolak dan Ha diterima.

2. Secara parsial (sendiri-sendiri), variabel tingkat absensi (X1), kerja sama(X2) dan kepuasan kerja(X3) memiliki pengaruh terhadap kinerja perangkat nagari. Namun kedisipinan (X4) tidak memiliki pengaruh yang besar terhadap kinerja perangkat nagari di Kabupaten Pesisir Selatan.

Berdasarkan hasil temuan dan kesimpulan yang telah diuraikan di atas, maka penulis merekomendasikan saran-saran sebagai berikut:

1. Hasil penelitian menunjukkan bahwa sub variabel tingkat absensi, kerja sama dan kepuasan kerja perangkat nagari berpengaruh secara signifikan terhadap kinerja perangkat nagari dalam pengelolaan keuangan nagari di Kabupaten Pesisir Selatan. Maka dari itu disarankan kepada setiap pemerintah nagari agar lebih mempehatikan semangat kerja perangkat nagari yang mencakup tingkat absensi (kehadiran), kerja sama, dan kepuasan kerja dalam pengelolaan keuangan nagari agar kinerja perangkat nagari dalam pengelolaan keuangan nagari juga meningkat.

2. Peneliti menyadari bahwa hasil penelitian ini masih jauh dari kata sempurna dan memiliki kelemahan tertentu, maka dari itu kepada peneliti selanjutnya diharapkan agar lebih menyempurnakan penelitian ini dengan melakukan penelitian yang lebih mendalam sekaligus menyertakan berbagai variabel lain yang memiliki pengaruh terhadap pengelolaan keuangan nagari di Kabupaten Pesisir Selatan. 


\section{DAFTAR KEPUSTAKAAN}

\section{Referensi dari Buku dan Jurnal}

Flippo, E. B. (2005). Manajemen Personalia (keenam; M. Masud, ed.). Jakarta: Erlangga.

Griffin, Ricky W dan Elbert, R. J. (2007). Bisnis (Delapan). Jakarta: Erlangga.

Handayani, R. D. (2016). Pengaruh Lingkungan Dan Semangat Kerja Terhadap Kinerja Pns Balitsa Lembang. Pariwisata, April, II(2), 40-51.

Haryadi, W. (2016). Pengaruh Semangat Kerja Dan Disiplin Kerja Terhadap Kinerja Pegawai Puskesmas Kecamatan Maronge Kabupaten Sumbawa Tahun 2015.

Hasibuan, M. S. . (2005). Manajemen Sumber Daya Manusia (Revisi). Jakarta: Bumi Aksara. Murtiono, Y. (2016). Modul Tata Kelola Keuangan Desa. Yogyakarta: Infest.

Murty, Windy Aprilia dan Hudiwinarsih, G. (2012). Pengaruh Kompensasi, Motivasi Dan Komitmen Organisasional Terhadap Kinerja Karyawan Bagian Akuntansi (Studi Kasus Pada Perusahaan Manufaktur Di Surabaya). The Indonesian Accounting Review, 2(2), $215-228$.

Nawawi, H. (2013). Sumber Daya Manusia Untuk Bisnis yang Komptitif. Yogyakarta: Gajah Mada University Press.

Pratama, Abdul Aziz Nugraha, dan Wardani, A. (2017). Pengaruh Kemampuan Kerja dan Semangat Kerja Terhadap Kinerja Karyawan Melalui Kepuasan Kerja (Studi Kasus Bank Syariah Mandiri Kantor Cabang Kendal). Jurnal Muqtasid, 8(2), 119-129.

Siagian, S. P. (2010). Manajemen Sumber Daya Manusia. Jakarta: Bumi Aksara.

Syahropi, I. (2016). Pengaruh Semangat Kerja Terhadap Kinerja Karyawan Pt. Bangkinang Di Pekanbaru (Studi Kasus Pada Karyawan Tetap Pt. Bangkinang). JOM FISIP, Oktober, 3(2), 1-12.

Syamsir. (2017). Model Pembinaan Kapasitas Aparatur Pemerintah Nagari dalam Pengelolaan Keuangan Nagari di Kabupaten Tanah Datar Provinsi Sumatera Barat. Padang: Universitas Negeri Padang.

Syamsir dan Baiyulis. (2018). Pengaruh Kepuasan Kerja Terhadap Kinerja Perangkat Nagari Dalam Pengelolaan Keuangan Nagari Di Kecamatan Sungai Tarab Dan Salimpaung. Journal of Education on Social Science, 2(2), 73-84.

Syamsudin, A. (2005). Psikologi Pendidikan. Bandung: PT. Remaja Rosdakarya.

Wibowo. (2016). Manajemen Kinerja (Kelima). Jakarta: Raja Grafindo Persada.

\section{Referensi dari Peraturan Perundang-Undangan:}

Peraturan Bupati Pesisir Selatan Nomor 69 Tahun 2016 tentang Pedoman Pengelolaan Keuangan Nagari.

Peraturan Bupati Pesisir Selatan Nomor 64 Tahun 2016 tentang Susunan Organisasi dan Tata Kerja Pemerintahan Nagari

Peraturan Pemerintah Nomor 47 Tahun 2015 tentang Peraturan Pelaksanaan Undang-Undang Nomor 6 Tahun 2014 tentang Desa

Peraturan Menteri Dalam Negeri Nomor 113 Tahun 2014 Tentang pengelolalan Keuangan Desa

Undang-Undang Republik Indonesia Nomor 6 Tahun 2014 tentang Desa.

\section{Sumber Berita:}

Detik News. 2017. Mengalihkan Korupsi Ke Pedesaan (https://m.detik.com/ news/opini/d3699457/mengalihkan-korupsi-ke-pedesaan) Diakses pada tanggal 12 Januari 2019 